\title{
EPS VAGY XPS? IRODALMI ÁTTEKINTÉS
}

\author{
Voith Katalin \\ tudományos fömunkatárs, Miskolci Egyetem, Energetikai és Vegyipari Gépészeti Intézet, \\ Vegyipari Gépészeti Intézeti Tanszék \\ 3515 Miskolc, Miskolc-Egyetemváros, e-mail: katalin.voith@uni-miskolc.hu \\ Petrik Máté \\ tanársegéd, Miskolci Egyetem, Energetikai és Vegyipari Gépészeti Intézet, \\ Vegyipari Gépészeti Intézeti Tanszék \\ 3515 Miskolc, Miskolc-Egyetemváros, e-mail:vegypet@uni-miskolc.hu
}

Spisák Bernadett

PhD hallgató, Miskolci Egyetem, Energetikai és Vegyipari Gépészeti Intézet, Vegyipari Gépészeti Intézeti Tanszék

3515 Miskolc, Miskolc-Egyetemváros, e-mail: spisak@uni-miskolc.hu

\section{Szamosi Zoltán}

egyetemi docens, Miskolci Egyetem, Energetikai és Vegyipari Gépészeti Intézet, Vegyipari Gépészeti Intézeti Tanszék

3515 Miskolc, Miskolc-Egyetemváros, e-mail:szamosi@uni-miskolc.hu

\section{Szepesi Gábor}

egyetemi docens, Miskolci Egyetem, Energetikai és Vegyipari Gépészeti Intézet, Vegyipari Gépészeti Intézeti Tanszék

3515 Miskolc, Miskolc-Egyetemváros, e-mail: szepesi@uni-miskolc.hu

\begin{abstract}
Absztrakt
A jelenlegi gazdasági életünk egyik legfontosabb kulcsszava a körkörös gazdaság. Ez annyit jelent, hogy az élet minden területén törekedni kell arra, hogy egy termék minél késöbb váljon hulladékká. Végtermék helyett törekedni kell arra, hogy az adott termék másodlagos termékké válhasson. A termékek élettartamának a meghosszabbitása a cél, az, hogy egy eddig végtermékként, hulladékként kezelt anyag újabb esélyt kaphasson azzal, hogy az eddigi életciklusa végén további feldolgozásra kerül. Ennek jegyében kezdtük el a kísérleteket olyan megerösitett EPS anyag elöállitására, ami fizikai és hötani tulajdonságaiban fel tudja venni a piaci versenyt az XPS termékekkel, amik elöállitási fajlagos költsége jóval magasabb az EPS-nél. A megerösitéshez pedig olyan anyagokat választunk, amik jelenlegi életciklusuk szempontjából végterméknek, azaz hulladéknak minösülnek, mint például a müanyag szívószál. Ehhez a kutatómunkához alapvetö, hogy feltérképezzük az alapanyagokat, azaz az EPS-t és az XPS-t. A cikk a szakirodalomban talált releváns információkat gyüjti össze a kétféle anyag tulajdonságait és a hozzájuk kapcsolódó szimulációs vizsgálatokat illetően.
\end{abstract}

Kulcsszavak: körkörös gazdaság, EPS, XPS, FEM szimuláció

\section{Abstract}

One of the most important keywords in our current economic life is the circular economy. This means that on all platform of life we need to intend making a product become a waste as late as possible. Instead of an end product, the goal is to return it to the economy as a basic of a new product. The aim 
is to extend the lifetime of a products. Instead of generating waste, a new chance has to be given by reusing it at the end of its lifetime. Based on this thought our research work was begun with the goal of producing reinforced EPS material, which has the physical and thermal properties at least as good as the XPS that is much more expensive to produce. For reinforcement, materials have been chosen that, in terms of its current life cycle, is considered an end product, i.e. waste. The first choice are plastic straws and cutleries that will be redraw from the market. It is essential for this research work to map the raw materials, i.e. EPS and XPS. The article collects the properties of the EPS and XPS and the related simulation methods that can be found in the literature.

Keywords: EPS, XPS, Simulation, Circular economy

\section{Bevezetés}

Az EPS (expandált) és az XPS (extrudált) egyaránt zárt cellás merev szigetelés, amely ugyanabból az alapanyagból, polisztirol gyantából készül. Azonos kémiai összetételú polisztirol habok, de a gyártásmódjuk eltérő.

Az EPS, expandált polisztirol hab, hőre lágyuló, cellás (sejtes) szerkezetű polisztirol keményhab hőszigetelö-anyag. Kis testsürüségü - $10-30 \mathrm{~kg} / \mathrm{m}^{3}$, könnyen kezelhető anyag.

Az XPS, extrudált polisztirol hab, extrudáló-habosító eljárással készült kemény, zártcellás anyagszerkezetü polisztirolhab. Az EPS-el ellentétben tömböt nem lehet gyártani XPS extrudált polisztirol keményhabból, csak táblát. Testsürüsége $25-50 \mathrm{~kg} / \mathrm{m}^{3}$, ami miatt a müszaki jellemzői lényegesen jobbak, mint az expandált PS haboké, viszont éppen ezért az áruk is jóval magasabb.

A cikk azt kívánja megalapozni, hogy kutatásainkat érdemes-e olyan irányba terelni, amely során az EPS-t a körkörös gazdaság jegyében olyan - föleg szilárdsági - tulajdonságokkal lássuk el, ami eléri az XPS habokét. Ehhez első lépésben feltérképezzük a szakirodalomban található információkat, az EPS és XPS anyagokat és alkalmazásaikat illetően, valamint a hozzájuk kapcsolódó szimulációs vizsgálatokról, vizsgálati módszerekről kívánunk egy összefoglalást készíteni.

Az Európai Unió 2019-ben elfogadta azt az indítványt, ami az egyszer használatos műanyagok piacról történő kivonására vonatkoznak. A termékek között vannak a mủanyag evőeszközök és szívószálak is - amit az EPS megerősítésére fel kívánunk használni kutatásunk során. Európában évente mintegy 25 millió tonna mủanyag hulladék keletkezik, aminek csupán a 30\%-a kerül újra feldolgozásra. A tengerparti hulladék 85\%-t teszi ki a müanyag hulladék. Ezért született az a rendelet, aminek értelmében tilos lesz forgalomba hozni olyan egyszer használatos müanyag termékeket, amelyeket ki lehet váltani más, könnyen beszerezhető és megfizethető termékekkel. [1]

A fókuszba helyezett anyagok leggyakoribb felhasználási területe az építőipar, ezen belül a hőszigetelés egyik legelterjedtebben használt alapanyagai. Az Európai Unió 2018/844 irányelvének megfelelően a tagállamoknak törekedniük kell az energiaellátás dekarbonizálása és a végső energiafogyasztás csökkentése közötti költséghatékony egyensúly megtalálására. Cél, hogy az új építésủ épületeknél is, de a felújítások során a nulla energiaigényü épületek elérése legyen az egyik fö szempont. [2][3]

\section{Expandált és extrudált polisztirol mechanikai tulajdonságai}

Napjaink építőipara számára az egyik legfontosabb feladat, hogy olyan épületeket hozzanak létre, amik környezetre gyakorolt negatív hatása minimális és ezzel egyidejüleg az energia hatékonysága pedig a lehető legjobb legyen. Ennek érdekében a hőszigetelés, azok anyagai és eljárástechnológiájuk előtérbe került. A leginkább hőszigeteléshez használt - természetesen egyéb anyag fajták mellett anyagok az EPS,XPS valamint az ásványgyapot. 
Ahogy azt a bevezetőben is említettük, mind az EPS, mind az XPS polisztirol hab, azonos kémiai összetétellel, viszont a nagy különbség közöttük az eljárás, amiként előállítják őket. Az EPS, angol nevén expanded polystyrene, expandált polisztirol hab, míg az XPS, angol nevén extruded polystyrene, azaz extrudálás útján elóállított polisztirol hab.

\subsection{EPS és megerősített EPS}

Az EPS anyagok megbízható szigetelő anyagok és hosszú távon nyújtanak mind belső, mind külső védelmet az épület falai számára. Zárt cellás szerkezetének köszönhetően kiváló védelmet nyújt a nedvességgel szemben. A sürüsége, szilárdsága és a vastagsága határozza meg hőállóságát és kompressziós terhelhetőségét. Használhatóak falak, plafonok, padlók és tetők szigetelésére is. Az 1. ábra fal szigetelésére mutat be egy gyakorlati példát.

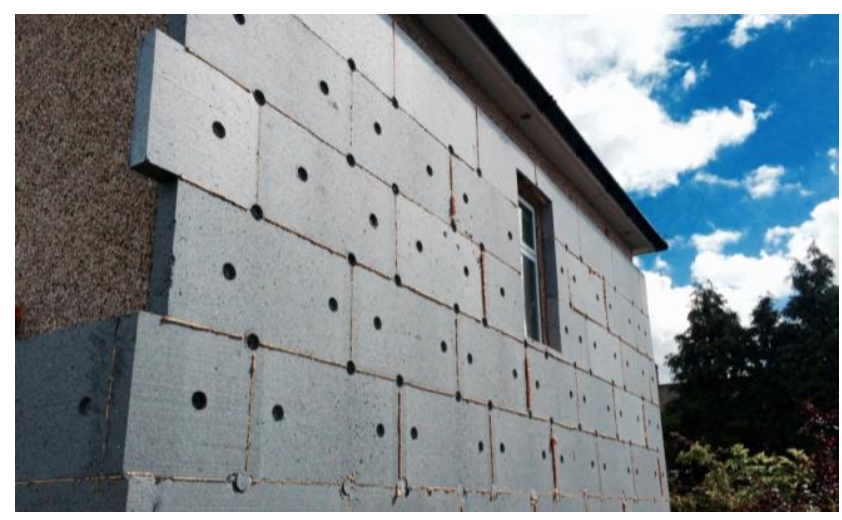

1. ábra. EPS szigetelö lapok ház falán [4]

Az EPS szigetelő habok nyomószilárdságát vizsgálva megállapítható, hogy a hab sürüsége befolyásolja annak mechanikai tulajdonságait. Mivel az EPS jól tömöríthető, ezért ideális a pórusos anyagában keletkező a horizontális és vertikális feszültség csökkentésére, miközben az oldalirányú elmozdulás szinte elhanyagolható nagyságú. A nyomószilárdság nagymértékben függ az anyag sủrüségétől, az anyagváltozás vagy deformáció mértékétől és az alkalmazott nyomóerő nagyságától. Amikor a feszültséget fokozatosan növeljük, több EPS buborék tủnik el és ezzel egy alacsonyabb nyomószilárdság figyelhető meg. Az EPS sürüségének növekedése a nyomószilárdság növekedését eredményezi. A rugalmassági modulus (Young modulus) értékének növekedése figyelhető meg nagyobb sűrüségü EPS-nél és a nyomófeszültség növekedésekor. Tehát elmondható, hogy az alakváltozási sebesség növekedésekor mind a rugalmassági mutató, mind a nyomófeszültség növekszik. A rugalmassági mutatóra nagyobb hatással van az alakváltozási sebesség sủrübb szerkezetű EPS esetén, míg a teljes minta szilárdsága a rugalmas alakváltozás helyén érzékenyebb az alakváltozás sebességére kisebb sűrüségü EPS-ek esetében, ami a buborékok sérülésével van összefüggésben. Az 1. táblázatban négy különbözö sürüségü EPS anyag tulajdonságai láthatóak. [5]

1. táblázat. EPS anyagtulajdonságok

\begin{tabular}{|l|c|c|c|c|}
\hline Jellemzők & EPS70 & EPS100 & EPS150 & EPS200 \\
\hline Sürüség, $\mathrm{kg} / \mathrm{m}^{3}$ & 13,5 & 18,0 & 23,0 & 28,0 \\
\hline Kiindulási rugalmassági mutató, MPa & 2,5 & 4,0 & 5,0 & 7,5 \\
\hline $\begin{array}{l}\text { Nyomószilárdság 10\%-os tengelyirányú terhelés } \\
\text { esetén, }[\mathrm{kPa}]\end{array}$ & 70 & 110 & 135 & 200 \\
\hline
\end{tabular}


Az Európai Unióban az összes energiafogyasztás mintegy 40\%-t az épületek energiafogyasztása teszi ki, ezen felül még a kibocsátott $\mathrm{CO}_{2} 35 \%$-a is a korszerütlen épületeinknek köszönhető. A lapos tetők, mint az épület rétegződésének egyik eleme, nagy szerepet játszik a hőveszteségben - természetesen az épület szerkezetének, magasságának függvényében. a lapos tetők szigetelésében az EPS lapok kiváló hőszigetelést biztosítanak, lecsökkentik a hőveszteséget. Az EPS-t nem csak lapokban lehet e célból a tető szerkezetében alkalmazni, hanem az EPS granulátumot a cementhez keverve, könnyü szerkezetü beton (2. ábra) is kiválóan ellátja ezt a hőszigetelési feladatot. [6]

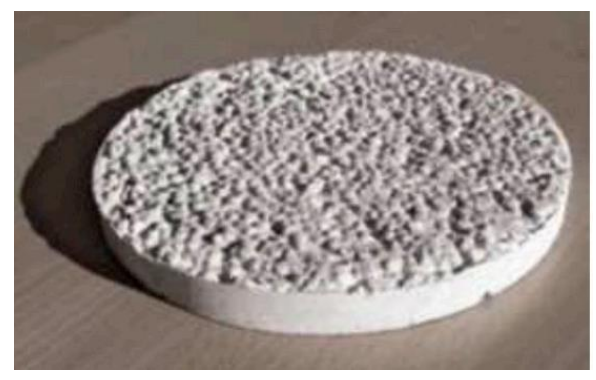

2. ábra. EPS granulátumú cement korong [6]

Az épületek szigetelésével kapcsolatban nemcsak a hőszigetelési előírásokat és igényeket kell figyelembe venni, hanem a hangszigetelését is. Az EU elöírások arra ösztönzik a tagállamokat, hogy odafigyeljenek a hangszigetelésre is, hiszen a környezeti zajártalom globális probléma. Ha az EPS-t megfelelő vastagságú vakolattal kombináljuk jelentős eredményeket lehet elérni. [7] Ilyen kombinált szerkezetet mutat be a 3 . ábra.

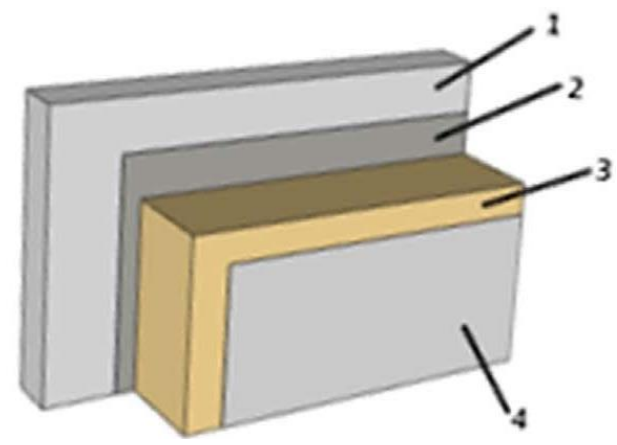

3. ábra. Alapfalra felvitt EPS vakolattal

1: alapfal, 2: ragasztóanyag, 3: EPS, 4: vakolat [7]

Ha az alapfalra felrakott EPS-re felvisznek egy $5 \mathrm{~mm}$ vastagságú vakolat réteget, akkor azzal jelentôs - 8-16 dB - hangszigetelési érték növekedést lehet elérni a $630 \mathrm{~Hz}$ feletti frekvencia tartományban. Ha tovább növeljük a vakolat rétegvastagságát még $5 \mathrm{~mm}$-rel - tehát a vakolat réteg így $10 \mathrm{~mm}$ - az EPS hangszigetelő képessége megnő 5 dB-re a 630-1000 Hz-es frekvencia tartományban.

Az EPS-nek az építőiparhoz kapcsolódó, de kicsit másféle felhasználásáról számol be egy tanulmány az olaszországi útépítésekhez köthetően. Az expandált polisztirol egy hőre lágyuló anyag, amit elöre feldúsított polisztirol gyöngyökböl készítenek, így a kimagaslóan könnyü tömege ellenére is nagy a szilárdsága és hőszigetelö képessége. Ezeknek a tulajdonságainak köszönheti, hogy a természetes anyagok alternatívája lehet olyan építészeti projektek során, amik egyébként nagy költségvetésüek vagy időigényesek lennének, vagy akár ki sem lehetne őket vitelezni. Olaszországban már húsz éve 
sikeresen alkalmazzák az EPS-t a közúti infrastruktúra területén, konkrétan utak, hídcsatlakozók, könnyű töltések és utántöltések megvalósításában, de mindenekelőtt a veszélyeztetett utak - földcsuszamlás, vibráció - megépítésénél és javításánál. [8]

\subsection{XPS}

Az extrudált polisztirol hab, azaz az XPS gyártása szilárd polisztirol kristályokból kezdődik. Ezeket a kristályokat különböző adalék- és habosítóanyagokkal egy extrúderbe kerül. Ez a keverék az extrúderben ellenőrzött körülmények között magas hőmérsékleten és nagy nyomáson elnyeri végső, viszkózus folyékony mủanyag állapotát. Ezt a sürü, forró olvadékot egy folyamatos sajtolóba vezetjük. A sajtolóból kilépve habbá duzzad, elnyeri végső alakját, majd elhülve méretre vághatóvá válik.

Az XPS cella szerkezete teljesen zárt, nincsenek benne üregek a sejtek között. Ez teszi az XPS-t ellenállóvá nyomással és nedvességgel szemben. a szerkezete homogén és nem törhető könnyen darabjaira. [9]

Az extrudált polisztirol hab jobb hőszigetelési tulajdonságokkal rendelkezik, mint az EPS, ezért az egyik közkedvelt alkalmazási területe a talaj szigetelése, ahol nemcsak a jobb höszigetelési tulajdonsága miatt alkalmazzák inkább, mint az EPS, hanem azért is, mert a mechanikai tulajdonságai is jobbak, hisz ezek a felületek terhelés (lépés) állóak is kell legyenek.

\subsection{EPS és XPS összehasonlítása}

Az előző részekben külön-külön beszéltünk az EPS-ről és az XPS-röl. Ebben a részben összehasonlítjuk a két anyagot különböző szempontok alapján. Először is beszéltünk már a két anyag szerkezetéről: az EPS kis polisztirol gyöngyökből készül gőzöléssel egy öntőformában, ahol a gyöngyök megduzzadnak és összetapadnak, de közöttük rések találhatók, amik miatt a vizet könnyebben fel tudja szívni, mint az XPS, aminek teljesen zárt cellás szerkezete van. A szerkezeti különbséget a 4 . ábra mutatja be. [10]

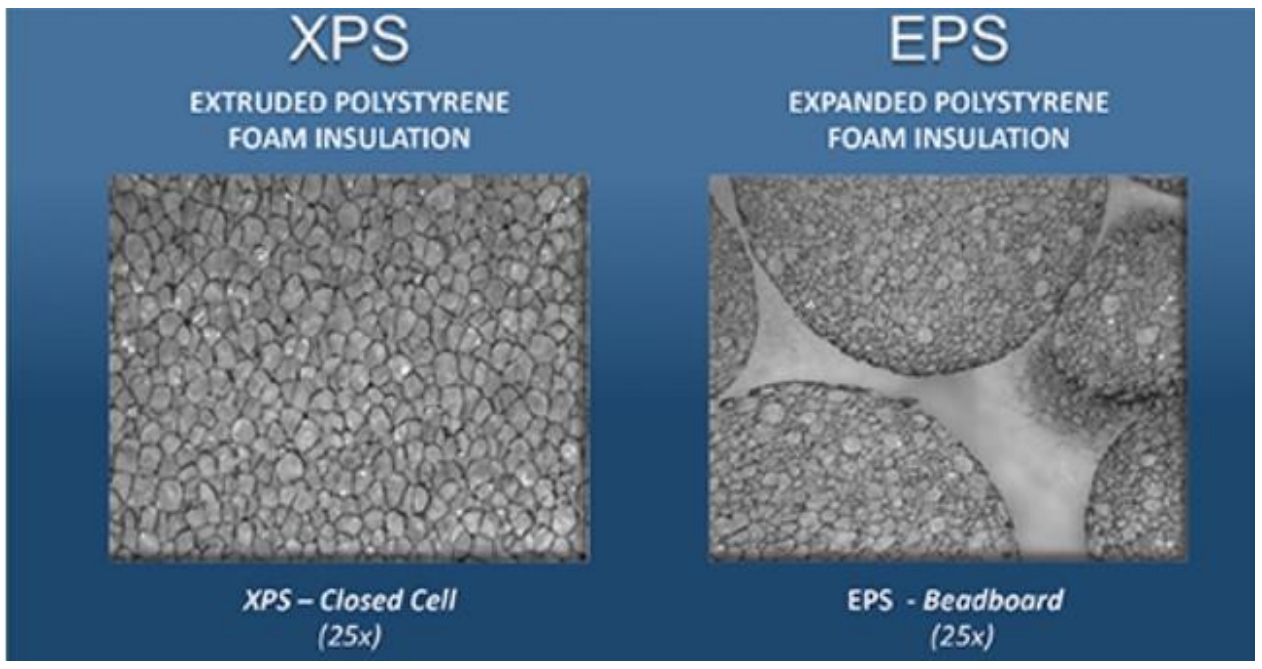

4. ábra. XPS és EPS szerkezete [10]

A 2. táblázatban összefoglaljuk az EPS és XPS néhány fizikai tulajdonságát. Az építőiparban elterjedt az R-érték fogalma, ami az egységnyi felület hő-ellenállását mutatja. [11][12] 
2. táblázat. EPS és XPS fö fizikai tulajdonságai

\begin{tabular}{|l|c|c|}
\hline \multicolumn{1}{|c|}{ Fizikai tulajdonság } & EPS & XPS \\
\hline Sürüség, $\mathrm{kg} / \mathrm{m}^{3}$ & 34 & 50 \\
\hline Hővezető képesség, W/mK & 0,035 & 0,030 \\
\hline Nedvesség felszívó képesség & 5 & 1 \\
\hline R-érték (kb. $\left.24^{\circ} \mathrm{C}-o n\right), \mathrm{m}^{2} \mathrm{~K} / \mathrm{W}$ & 4,1 & 5,0 \\
\hline Nyomásállóság, psi & $10-25$ & $15-100$ \\
\hline
\end{tabular}

Az XPS-nek vannak előnyei az EPS-sel szemben, mint a kisebb abszorpciós képesség és a jobb szilárdság, ez viszont a két anyag árában is megmutatkozik, hiszen az XPS termékek ára 50-80\%-kal magasabbak, mint az EPS termékeké. [13]

\section{Vizsgálati lehetôségek}

Egy termék, anyag megfelelöségének ellenőrzésére a legelterjedtebb módszer a mérések alkalmazása, azonban napjainkban egyre jobban előtérbe helyeződik a végeselemes szimulációk végzése, mivel ezzel az eljárással a modell validálását követően nincs szükség további mintadarabok elkészítésére, és eltérő terhelések mellett meghatározható az adott anyagból készült termék megfelelősége. Expandált polisztirol esetében a szimuláció során a legnagyobb kihívást az anyagmodell helyes megadása jelenti. Ennek egyik oka az, hogy a tulajdonságai függenek az alakváltozási sebességtől, illetve a polimer habok sürüségétől, ezért az anyagmodell kialakítása nagymértékben függ a hab sürüségétől és alkalmazási területüktől. A megfelelő anyagmodell kiválasztását követően a paraméterek meghatározásához szükséges méréseket elvégezni.

\subsection{Szimulációhoz szükséges laboratóriumi mérés}

Az 5. ábra egy EPS hab feszültség alakváltozás diagramját mutatja be. Az ábrából látható, hogy a görbe három részre bontható, a lineárisan rugalmas szakaszra, a nagy alakváltozási szakaszra, ahol a feszültség értéke közel konstans növekvő alakváltozás mellett és a sürítés szakaszra, ahol kis alakváltozás mellett a feszültség gyors exponenciális növekedése figyelhető meg. Amikor egy habot összenyomunk, akkor a benne lévő golyócskák falai elkezdenek elhajolni, amely egy lineárisan rugalmas alakváltozáshoz vezet, egy kritikus alakváltozási értéket meghaladva ezek a golyócskák rugalmas kihajlás hatására összeomlanak minden egyes alkalommal, amikor ellentétes golyó falak összeérintkeznek. Ahogy a golyócskák összezáródnak a szerkezet elkezd besürüsödni, ezáltal az anyag merevsége gyorsan növekszik. Ennek a görbének a meghatározására nyomóvizsgálat készítése szükséges.

Kvázistatikus vizsgálat esetében a mintadarab leggyakrabban alkalmazott kialakítása a hengeres próbatest [14], Bertholf és Karen [15] tanulmányában az elvégzett vizsgálatok azt mutatták, hogy a laterális és az axiális inercia, illetve a súrlódás további kényszereket hozhatnak létre, amely többtengelyű feszültségi állapothoz vezethet, ezért a henger magassága és átméröje közötti optimális arányt 0.5 nek ajánlják. A hengeres kialakítás mellett még kocka, illetve téglatest alakú próbatesteket alkalmaznak [16][17].

A kvázistatikus nyomóvizsgálatokat általában több alacsony alakváltozási sebességen végzik el. A nyomóvizsgálatból származó feszültség-alakváltozás diagramból már meghatározható a rugalmassági modulus, illetve az összenyomott próbatestből megállapítható egy fontos, a későbbi szimulációs beállításoknál használt paraméter értéke, mégpedig a Poisson tényező. Az EPS habok összenyomásakor nem figyelhető meg laterális megnyúlás, amely alapján az ilyen EPS habok Poisson tényezője zérus, 
az anyag térfogata nem állandó a vizsgálat során, vagyis a próbatest sűrüsége növekszik [16][18]. Kvázistatikus nyomóvizsgálat mellett még szakítóvizsgálatra, ütőpróbára, illetve dinamikus nyomó/húzó vizsgálatra lehet találni példát a szakirodalomban, azonban a végeselemes szimuláció validálásához elegendő a nyomóvizsgálat elvégzése.

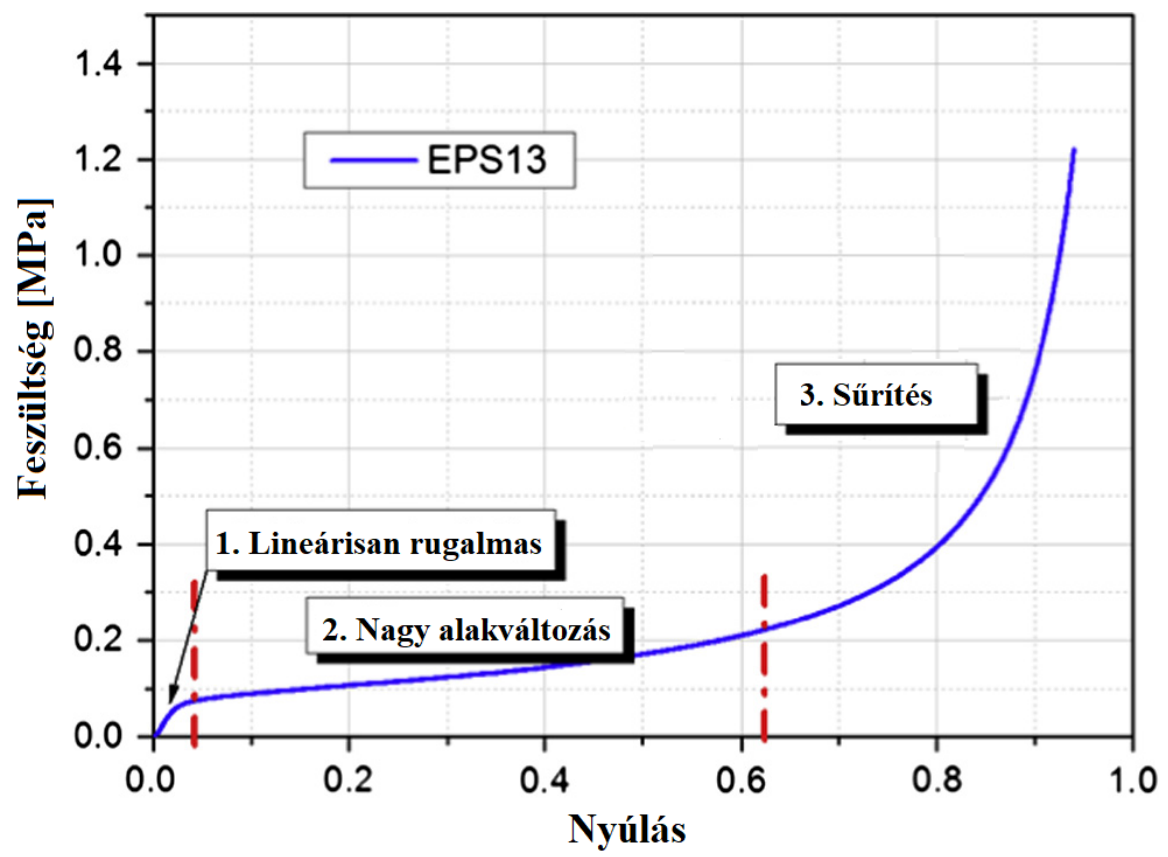

5. ábra. EPS 13 Feszültség-nyúlás diagramja [14]

\subsection{EPS végeselemes szimulációja}

A szakirodalomban több példa is található PS habok végeselemes szimulációjára. A következőkben ezeknél a szimulációknál alkalmazott beállítások és eredmények kerülnek bemutatásra. Az egyik legkorábbi, ide sorolható szakcikk XPS habok 2D-s és 3D-s ütőpróba vizsgálatának szimulálásával foglalkozik [18]. A szerzők a szimulációkat ABAQUS Standard 6.2-es verziójában készítették el, ahol a kapott eredmények a kísérletek során kapott adatokat jól megközelítették.

Gerhard Slik és társai [19] már expandált polisztirol hab vizsgálatát végezték el. A kiválasztott anyag esetén az alakváltozási sebesség nem befolyásolta jelentősen az eredményeket, ezért a szimuláció során sem vették ezt figyelembe. A szimulációkat LS-DYNA szoftver segítségével készítették el, ebben a szoftverben számos hab anyagmodell alkalmazása lehetséges, ezek közül a szerzők egy nagy mértékben összenyomható, kis sủrüségü, rugalmas habra (Material Type 57) és egy kis mértékben rugalmas habra (Material Type 63) vonatkozó anyagmodellt, és kis csillapítási tényezőt alkalmaztak. A két anyagra vonatkozó terhelés elmozdulás diagramot a 6. ábra szemlélteti ahol látható, hogy a két modell között a különbség a terhelés megszünését követöen az anyag rugalmasságában van. Az 57-es anyag esetén a terhelés megszünésével az anyag visszanyeri az eredeti alakjának egy részét, míg a 63as anyag esetén a terhelés megszünésével a próbatest a deformálódott alakban marad.

Az anyagmodell kiválasztását követően háromféle szimulációt végeztek el, ütővizsgálatot, dinamikus fejet érő ütővizsgálatot, illetve dinamikus medencecsontot érő ütővizsgálatot. Az utóbbi kettő lényege az volt, hogy a deformáció ne egyirányú legyen. A feszültség alakváltozás diagramot az egysze- 
rü ütővizsgálatból határozták meg, majd az anyag modell validálásához a további két vizsgálat kísérletét és szimulációját is elkészítették, amelyeknek közel azonos eredményeik voltak az első és a második vizsgálat esetében, azonban a fejet érö ütővizsgálat esetén további változtatásokra van szükség.
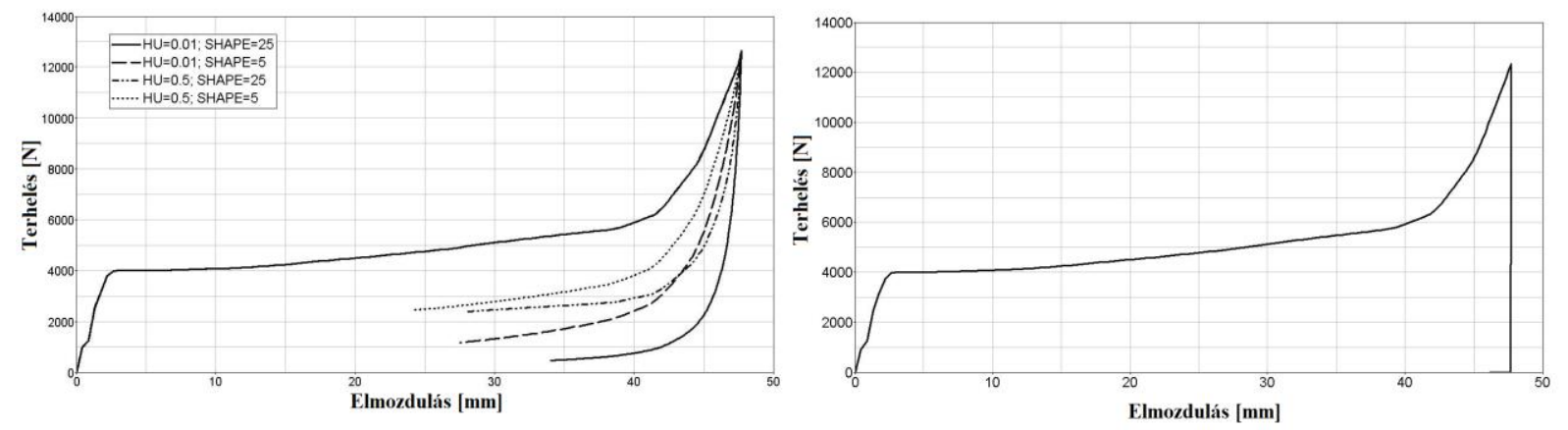

6. ábra. 57-es (bal) és 63-as (jobb) anyag terhelés-elmozdulás diagramja [19]

Ozturk és Anlas tanulmánya [20] is az EPS habbal foglalkozik, azonban az előzőktől eltérően ebben többszörös terhelési és tehermentesítési esetet vizsgáltak, mivel energia elnyelö komponensek esetében fontosabb annak a meghatározása, hogy egy adott elnyelt energia esetében pontosan meg tudjuk határozni a terhelés alatt a maximális elmozdulást, erőt és lassulást, mint a maradó deformációját, a feszültség nyúlás diagramját és az energia felszabadulását tehermentesítés során. Az általuk használt szoftverek az LS-DYNA és az ABAQUS. Az ABAQUS esetében a törhető hab anyagmodell alkalmazása térfogati felkeményedéssel jó megoldást adott, a kiválasztott alapanyag az EPS20 volt. Ez az anyagmodell a deviátoros feszültség és a hidrosztatikus feszültségmezőben egy elliptikus folyási felületet használ, amelyhez kettő paraméter szükséges: nyomó folyási arány (compression yield ratio), amely egytengelyü nyomás esetében a kezdeti folyáshatár és hidrosztatikus nyomásnál a kezdeti folyáshatár aránya. A második a hidrosztatikus folyáshatár arány, amely hidrosztatikus szakítóvizsgálatnál keletkező szakítószilárdság és hidrosztatikus nyomóvizsgálatnál keletkező kezdeti folyáshatár aránya. Emellett a felkeményedés számításához még szükséges a folyáshatár $\left(\sigma_{y}\right)$ és az egytengelyủ képlékeny alakváltozás $\left(\varepsilon^{\mathrm{pl}}{ }_{\text {axial }}\right)$ meghatározása. $\mathrm{Az} \varepsilon^{\mathrm{pl}}{ }_{\text {axial }}$ meghatározható a nominális mérnöki alakváltozásból:

$$
\varepsilon_{\text {axial }}^{p l}=\ln \left(1+\varepsilon_{\text {nom }}\right)-\varepsilon^{e l}
$$

Ahol $\varepsilon_{\text {nom }}$ a névleges mérnöki nyúlás (nyomás esetében negatív), $\varepsilon^{\text {el }}$ a rugalmas alakváltozás. Az ezzel a modellel elvégzett szimulációk az első ütés esetén az impakt/ütközési tényezôt (G) jól meghatározták, azonban több becsapódás esetében a szoftver magasabb értékeket számolt. Az LS-DYNA szoftverben végzett szimulációk során a már korábban kis sürüségü hab anyagmodellt (MAT57) alkalmazták, mivel ebben az esetben a tehermentesítés, az újraterhelés, elmozdulás görbe alakját és hiszterézisét szabályozni lehet két paraméter segítségével. Ebben az esetben egyszeres terhelésú vizsgálat névleges feszültség és alakváltozás adataira van szükség. Maga az alapmodell nem volt jól alkalmazható a többszörös terhelésnek kitett komponensek vizsgálatára, viszont a MAT 57 anyag hiszterézis és alak tényező kalibrálásával a szimulációk pontosan elöre jelezték az impakt tényező értékét a G kis és nagy növekedése esetében is. Így elmondható, hogy az LS-DYNA anyagmodellje esetében a szerzők által kialakított kalibrálási eljárás más habok esetében is alkalmazható.

Ozturk és Anlas munkája alapján Shah és Topa [16] is ugyanezt az anyagmodellt alkalmazta a kvázistatikus vizsgálatai során az LS-DYNA szoftverben. Ehhez az öt szükséges paraméter az anyag 
sűrüsége, rugalmassági modulus, Poisson tényező, feszültség nyúlás görbe, szakítófeszültség és csillapítási tényező. Emellett még ütővizsgálatokat is végeztek, amely esetében az előző anyagmodell nem volt jól alkalmazható, mivel a nyomóerő a hab csak egy kis részét éri, így a nyomó erő mellett nyíróerö is keletkezik, ezért a modellhez további kiegészítéseket adtak:

- Anyag tönkremenetele (MAT_ADD_EROSION parancs módosításával) annak érdekében, hogy a hab rideg tönkremenetele szimulálható legyen.

- Az anyagmodell továbbfejlesztése a negatív térfogati hiba elkerülése érdekében (a feszültség nyúlás görbe meghosszabbítása exponenciálisan)

- Belső kontakt alkalmazása

A szimuláció során kapott eredmények jól fedik a mérésekét, ezért az elkészített modellfejlesztések alkalmasak kombinált terhelések esetén kialakuló feszültségek és alakváltozások pontos meghatározására. Az általuk kapott eredményeket mutatja be a 7. ábra.

Krundaeva és társai [17] az EPS hab dinamikus nyomószilárdságának a meghatározásával foglalkoztak, amelyhez Shah és Topa által továbbfejlesztett anyagmodellt alkalmazták. A szimulációkat LSDYNA szoftver segítségével végezték el, ahol az alakváltozási sebesség variálása mellett a sürüséget és a hőmérsékleteket is változtatták. Az eredmények azt mutatták, hogy a hőmérséklet befolyásolja az EPS szilárdságát, magas hömérsékleten $\left(50^{\circ} \mathrm{C}\right)$ csökkenést, alacsony hőmérsékleten $\left(-20^{\circ} \mathrm{C}\right)$ pedig szilárdság növekedést figyeltek meg. Az anyagmodellhez alkalmazott paraméterek segítségével pontosan elöre tudták jelezni az EPS hab terhelését és deformációját.

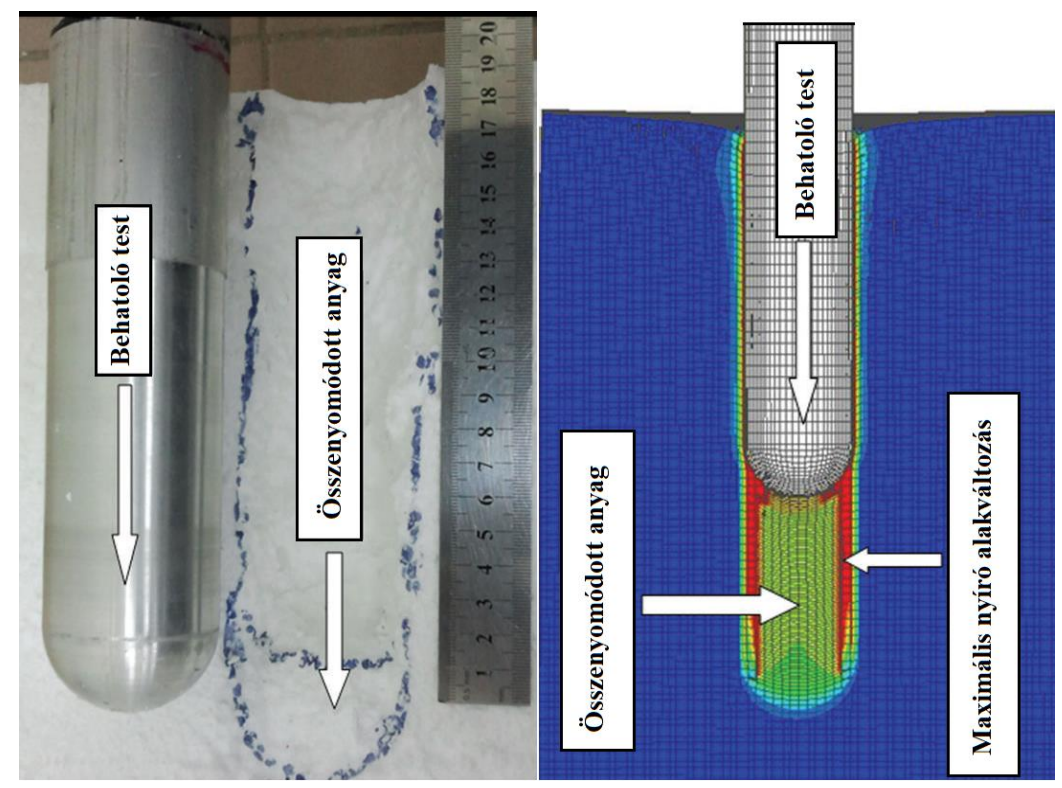

7. ábra. A hab tönkremenetelének folyamata mérés és szimuláció esetében [16]

\section{4. Összefoglalás}

A jelenlegi gazdasági életünk egyik legfontosabb kulcsszava a körkörös gazdaság, ami annyit jelent, hogy egy adott termék élettartama a lehető legtovább nyújtható legyen. Társadalmunk újra nem hasznosított hulladékának a legnagyobb részét mủanyagok képezik. A mủanyagok újra felhasználása nagy prioritást élvez napjainkban. Az általunk kutatott müanyag szemét újra felhasználási módja a PS habok 
müanyag alapú szívószálakkal történő megerősítése. A cikkben bemutattuk az EPS és XPS anyagokat. Ismertettük ezen anyagoknak az előállításit, szerkezeti felépítéseit, mechanikai tulajdonságait és felhasználási területüket. A két anyag kémiailag ugyan az, de a különböző eljárással történő előállítás miatt szerkezetük és mechanikai tulajdonságaik eltérőek.

Az elözőekben bemutatásra kerültek a szakirodalomban fellelhető expandált polisztirol esetén alkalmazott mérési és szimulációs tanulmányok, amelyekből megállapítható, hogy ennek az anyagnak a helyes modellezése egy igen bonyolult feladat, amelynek egyik fő oka az anyag több szakaszból álló feszültség-alakváltozás görbéje. A szimulációk során a szerzők túlnyomó többségben az LS-DYNA szoftvert használták a beépített kedvezö, habokra alkalmazható anyagmodellek miatt. Emellett néhány esetben az ABAQUS-t is alkalmazták, amelynek a beépített összetörhető hab anyagmodellje kvázistatikus esetben a mérésekkel közel azonos eredményeket produkált, viszont többszörös terhelés esetén a modell nem tudta teljes mértékben visszaadni a valós értékeket, míg az LS-DYNA szoftverben található anyagmodell paramétereinek korrigálásával az ilyen típusú terhelések is szimulálhatóak voltak.

\section{Irodalom}

[1] Single-use plastics: New EU rules to reduce marine litter https://ec.europa.eu/commission/presscorner/detail/en/IP_19_2631

[2] AZ EURÓPAI PARLAMENT ÉS A TANÁCS 2010/31/EU IRÁNYELVE, (2010. május 19.) az épületek energiahatékonyságáról (átdolgozás), https://eur-lex.europa.eu/legalcontent/HU/TXT/PDF/?uri=CELEX:32010L0031\&from=EN

[3] AZ EURÓPAI PARLAMENT ÉS A TANÁCS (EU) 2018/844 IRÁNYELVE, (2018. május 30.) az épületek energiahatékonyságáról szóló 2010/31/EU irányelv és az energiahatékonyságról szóló 2012/27/EU irányelv módosításáról; https://eur-lex.europa.eu/legalcontent/HU/TXT/PDF/?uri=CELEX:32018L0844\&from=EN

[4] https://ewistore.co.uk/working-with-expanded-polystyrene-eps-insulation (Letöltés: 2020. 05.28.)

[5] Khalaj, O., Siabil, S.M.A.G., Tafreshi, S.N.M., Kepka, M., Kavalir, T., Krizek, M., Jenicek, S.: The experimental investigation of behaviour of expanded polystyrene (EPS); Materials Science and Engineering 723 (2020) 012014 https://doi.org/10.1088/1757-899X/723/1/012014

[6] Gomes, R., Silvestre, J.D., de Brito, J.: Environmental life cycle assessment of the manufacture of EPS granulates,lightweight concrete with EPS and high-density EPS boards; Journal of Building Engineering 28 (2020); https://doi.org/10.1016/j.jobe.2019.101031

[7] Miskinis, K., Dikavicius, V., Buska, A., Banionis, K.: Influence of EPS, mineral wool and plaster layers on sound and thermal insulation of a wall: a case study; Applied Acustics 137 (2018) 62-68; https://doi.org/10.1016/j.apacoust-2018-03.001

[8] Giuliani, F., Autelitano, F, Garilli, E., Montepara, A.: Expanded polystyrene (EPS) in road construction: Twenty years of Italian experiences; Transportation research Procedia 45 (2020) 410-417 https://doi.org/10.1016/j.trpro.2020.03.033

[9] Lassen, C., Warming, M., Kjolholt, J., Jakobsen, L.G., Vrubliauskiene, N., Novichkov, B.: Survey of Polystyrene foam (EPS and XPS) in the Baltic Sea; Final report - Danish Fisheries Agency; February 2019

[10] Woestman, J.: Selecting polystyrene foam where moisture exposure occurs; https://www.constructionspecifier.com/selecting-polystyrene-foam-where-moisture-exposureoccurs/ (Letöltés: 2020. 05.28.) 
[11] Makai, A., Kiss, J., Mucsi, G.: The possibilities of Polystyrene waste recycling; https://doi.org/10.26649/musci.2016.008

[12] https://www.buildings.com/Portals/0/B_0609_SB_ENVELOPE_lg.jpg (Letöltés: 2020. 05.28.)

[13] https://akcios-hoszigeteles.hu (Letöltés: 2020. 05.28.)

[14] Wensu, C., Hao, H., Hughe,s D., Shi, Y., Cui, J., Li, Z.-X.: Static and dynamic mechanical properties of expanded polystyrene Materials and Design 69 (2015) 170-180 https://doi.org/10.1016/j.matdes.2014.12.024

[15] Bertholf, L., Karnes, C.: Two-dimensional analysis of the split hopkinson pressure bar system. J Mech Phys Solids 1975;23(1):1-19. https://doi.org/10.1016/0022-5096(75)90008-3

[16] Shah ,Q. H., Topa, A.: Modeling Large Deformation and Failure of Expanded Polystyrene Crushable Foam Using LS-DYNA Hindawi Publishing Corporation Modelling and Simulation in Engineering Volume 2014 https://doi.org/10.1155/2014/292647

[17] Krundaeva, A. et al.: Dynamic compressive strength and crushing properties of expanded polystyrene foam for different strain rates and different temperatures Polymer Testing August 2016 https://doi.org/10.1016/j.polymertesting.2016.08.005

[18] Masso-Moreu, Y., Mills, N.J.: Impact compression of polystyrene foam pyramids. Int J Impact Eng 2003;28(6):653-76. https://doi.org/10.1016/S0734-743X(02)00148-3

[19] Slik, G., Vogel, G., Chawda, V.: Material Model Validation of a High Efficient Energy Absorbing Foam. 5th LS-DYNA Forum, Ulm 2006

[20] Ozturk, U. E., Anlas, G.: Finite element analysis of expanded polystyrene foam under multiple compressive loading and unloading. Materials and Design 32 (2011) 773-780.

https://doi.org/10.1016/j.matdes.2010.07.025 